\title{
PENGARUH PEMBERIAN Lactobacillus TERHADAP GAMBARAN MIKROSKOPIS MUKOSA USUS HALUS TIKUS WISTAR (Rattus norvegicus) YANG DIINFEKSI DENGAN Escherichia coli
}

\author{
${ }^{1}$ Steviany Towoliu \\ ${ }^{2}$ Poppy Lintong \\ ${ }^{2}$ Carla Kairupan
}

\author{
${ }^{1}$ Kandidat Skripsi Fakultas Kedokteran Universitas Sam Ratulangi Manado \\ ${ }^{2}$ Bagian Patologi Anatomi Fakultas Kedokteran Universitas Sam Ratulangi Manado \\ Email: stevianytowoliu@ymail.com
}

\begin{abstract}
E. coli is part of the normal flora of the human and animal intestine and is commonly non pathogenic. However, one of the serotypes of this bacteria, which is enteropathogenic E. coli (EPEC), can cause primary infection on the intestine such diarrhea. The growth of pathogenic bacteria in diarrheal patients can be inhibited by Lactobacillus. Lactobacillus can function as probiotic which can affect the immune system of the digestive canals. In addition, Lactobacillus also produce mucus which can act as barrier to the pathogens. The objective of this study was to reveal the effects of the administration of Lactobacillus on the microscopic features of the mucosa of the intestine of wistar rats infected by Escherichia coli. This study was a laboratory experimental research employing 16 wistar rats divided into the control group (4 rats) and three treatment groups (12 rats) consisting of 4 rats each. Results showed that; in group I the histological features were normal, in group II part of the epithelium of the mucosa showed erosion, dilatation of the capillary vessels, and many lymphosites were observed, in group III the epithelium of the mucosa was intact and the number of lymphosites was liitle, and in group IV the surface of the epithelium was intact, the presence of cell regeneration indicated by the increase number of goblet cells and a small number of lymphocyes. Conclusions: The administration of after infection by E. coli has benefial effects indicated by the improvement of epithelial cells and the absence of denudation of the epithelium of the intestine.
\end{abstract}

Keywords: E.coli, Lactobacillus, intestinal mucosa.

\begin{abstract}
Abstrak: E.coli merupakan flora normal usus halus manusia dan hewan umumnya tidak menyebabkan penyakit. Namun salah satu serotipe E.coli yaitu E.coli Enteropatogenik (EPEK) bersifat patogen dan dapat menyebabkan infeksi primer pada usus misalnya diare. Pertumbuhan bakteri patogen pada pasien diare dapat dihambat oleh Lactobacillus. Lactobacillus merupakan probiotik yang akan mempengaruhi sistem imun saluran cerna serta memproduksi mukus yang berfungsi sebagai penghalang saluran cerna terhadap bakteri patogen. Penelitian ini bertujuan untuk melihat efek pemberian Lactobacillus terhadap gambaran mikroskopis mukosa usus halus tikus wistar yang diinfeksi dengan Escherichia coli. Penelitian ini merupakan penelitian eksperimental laboratorik. Subjek penelitian terdiri dari 16 ekor tikur wistar yang dibagi dalam kelompok kontrol (4 ekor) dan kelompok perlakuan (12 ekor) dibagi dalam 3 kelompok masing-masing 4 ekor. Hasil penelitian kelompok I dengan gambaran histologik jaringan usus normal, kelompok II sebagian epitel mukosa usus halus terlihat erosi, ada pelebaran pembuluh darah kapiler, dan banyak limfosit, kelompok III dengan permukaan epitel mukosa yang utuh dan jumlah limfosit sedikit, dan kelompok IV dengan permukaan epitel yang utuh, adanya regenerasi sel ditandai dengan bertambahnya sel goblet, dan sedikit limfosit. Simpulan: Pemberian Lactobacillus setelah
\end{abstract}


diberikan E.coli memberi efek yang baik berupa perbaikan sel epitel permukaan dan tidak terlihat denudasi epitel permukaan usus halus.

Kata Kunci: E.coli, Lactobacillus, mukosa usus halus.

E.coli merupakan flora normal usus halus manusia dan hewan umumnya tidak menyebabkan penyakit. Namun salah satu serotipe E.coli yaitu E.coli Enteropatogenik (EPEK) dapat menyebabkan infeksi primer pada usus misalnya diare. Berbagai mikroorganisme yang dilaporkan sebagai penyebab diare antara lain Escherichia coli, Rotavirus, Salmonella sp, Shigela sp, Campylobacter sp, dan Vibro cholerae. ${ }^{1}$ Diare karena infeksi bakteri ditularkan melalui fekal-oral dengan perantaraan lingkungan dan perilaku yang tidak sehat atau lebih sering melalui makanan, minuman, atau alat dapur yang terkontaminasi bakteri patogen dari feses manusia atau hewan.,

Pemberian probiotik pada penderita diare telah berkembang dengan pesat, walaupun masih terdapat kontroversi mengenai penggunaan probiotik dalam terapi diare akut. Probiotik adalah bakteri hidup yang bila diberikan atau dikonsumsi dalam jumlah cukup dapat memberikan efek menguntungkan bagi tubuh. Bakteri asam laktat (BAL) mempunyai sifat dasar sebagai probiotik dan menghasilkan senyawa antimikroba. Senyawa antimikroba yang dihasilkan oleh BAL ini mampu menghambat pertumbuhan bakteri enteropatogenik seperti Escherichia coli, Straphylococcus aureus, dan Salmonella typhimurium. Bakteri asam laktat seperti Lactobacillus dan Bifidobacterium merupakan kelompok bakteri yang umum digunakan sebagai mikroorganisme probiotik bagi konsumen.,

Berdasarkan uraian mengenai E.coli dan probiotik Lactobacillus, penulis tertarik untuk mengetahui bagaimana pengaruh Lactobacillus terhadap mukosa usus halus yang telah diinfeksi dengan E.coli.

\section{METODE PENELITIAN}

Penelitian ini merupakan penelitian eksperimental yang dilakukan pada bulan Oktober 2012-Februari 2013. Subjek penelitian terdiri dari 16 ekor tikus wistar yang dibagi dalam kelompok kontrol (4 ekor) dan kelompok perlakuan (12 ekor). Kelompok perlakuan dibagi lagi dalam 3 kelompok (masing-masing terdiri dari 4 ekor), yaitu kelompok I merupakan tikus kelompok kontrol negatif, kelompok II tikus yang diberi E.coli $10^{6} \mathrm{CFU}$ (1ml) selama 7 hari, kelompok III tikus yang diberi E.coli $10^{6} \mathrm{CFU}(1 \mathrm{ml})$ dan Lactobacillus $5 \times 10^{9} \mathrm{CFU} \quad(0,3 \mathrm{mg})$ secara bersama-sama, dan kelompok IV tikus yang diberi E.coli $10^{6} \mathrm{CFU}(1 \mathrm{ml})$ selama 7 hari dilanjutkan dengan pemberian Lactobacillus $5 \times 10^{9} \mathrm{CFU}(0,3 \mathrm{mg})$ selama 5 hari.

Tikus yang digunakan dalam percobaan ini adalah spesies Rattus norvegicus yang berumur sekitar 5 bulan dengan berat 130-170gram. Jaringan yang diteliti diambil dari usus halus sepanjang $1,5 \mathrm{~cm}$. Bakteri yang digunakan adalah E.coli dalam sediaan kultur $10^{6} \mathrm{CFU} / \mathrm{ml}$ (1ml/hari dosis tunggal) yang diberikan secara oral menggunakan nasogastric tube pediatrik nomor 5 selama 7 hari. Lactobacillus yang digunakan adalah Lactobacillus acidophillus 5 milyar $\left(5 \times 10^{9}\right)$ CFU dalam 0,3mg kapsul.

Tikus diterminasi dan dilakukan pengambilan jaringan untuk dibuat sediaan histopatologi pada gelas objek dan dilakukan pewarnaan dengan menggunakan pewarnaan rutin Hematoxylin-Eosin. Evaluasi sediaan dilakukan dengan menggunakan mikroskop cahaya.

\section{HASIL PENELITIAN}

Hasil penilaian gambaran mikroskopik jaringan usus halus dari tiap-tiap kelompok hewan uji menunjukkan gambaran yang relatif sama sehingga hanya dipilih beberapa slide yang baik untuk diambil fotonya.

\section{Tikus wistar kelompok I}

Tikus wistar kelompok I merupakan tikus kelompok kontrol negatif. Pada 
kelompok ini diperoleh gambaran histologik jaringan usus normal yang terdiri dari mukosa dengan epitel permukaan (sel epitel torak utuh) muskularis mukosa, submukosa, muskularis interna dan eksterna, dan serosa (Gambar 1).

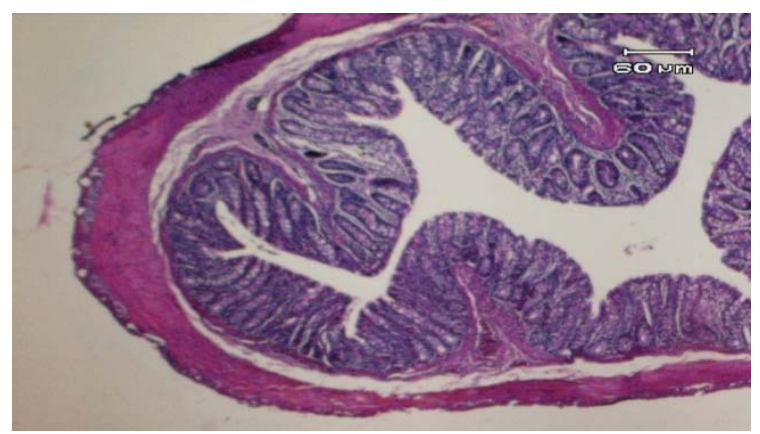

Gambar 1. Gambaran mikroskopik jaringan usus tikus wistar kelompok I. Tampak jaringan usus normal yang terdiri dari mukosa dengan epitel pelapis sel-sel epitel torak, muskularis mukosa, submukosa, muskularis eksterna, dan serosa. Pembesaran 4x10.

\section{Tikus wistar kelompok II}

Tikus wistar kelompok II merupakan kelompok tikus yang diberi E.coli $10^{6} \mathrm{CFU}$ (1ml) selama 7 hari. Pada kelompok ini arsitektur mukosa usus halus normal, tetapi sebagian epitel permukaan mengalami erosi (sel epitel denudasi). Ditemukan juga pelebaran pembuluh darah kapiler dan banyak limfosit pada lamina propia dan muskularis mukosa sampai submukosa (Gambar 2).

\section{Tikus wistar kelompok III}

Tikus wistar kelompok III merupakan kelompok tikus yang diberi E.coli $10^{6} \mathrm{CFU}$ (1ml) dan Lactobacillus $5 \times 10^{9} \mathrm{CFU}$ (0,3mg) secara bersama-sama. Arsitektur mukosa usus halus normal dengan permukaan epitel mukosa yang utuh, sedikit sel limfosit dan tidak ada pelebaran pembuluh darah (Gambar 3).

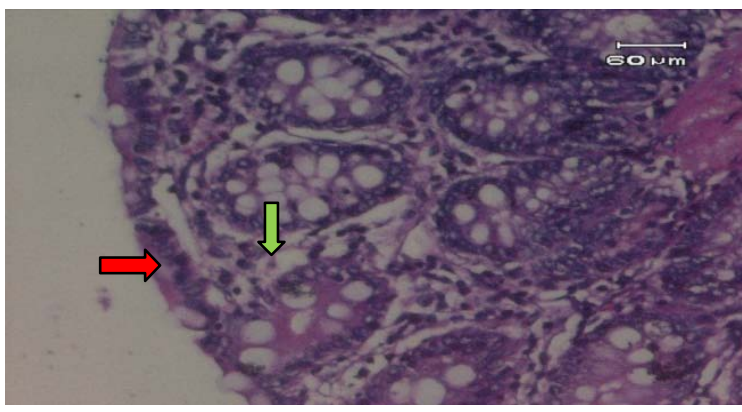

Gambar 3. Gambaran mikroskopik jaringan usus tikus wistar kelompok III. Epitel permukaan utuh (panah merah) dan sedikit sel limfosit (panah hijau). Pembesaran 20x10.
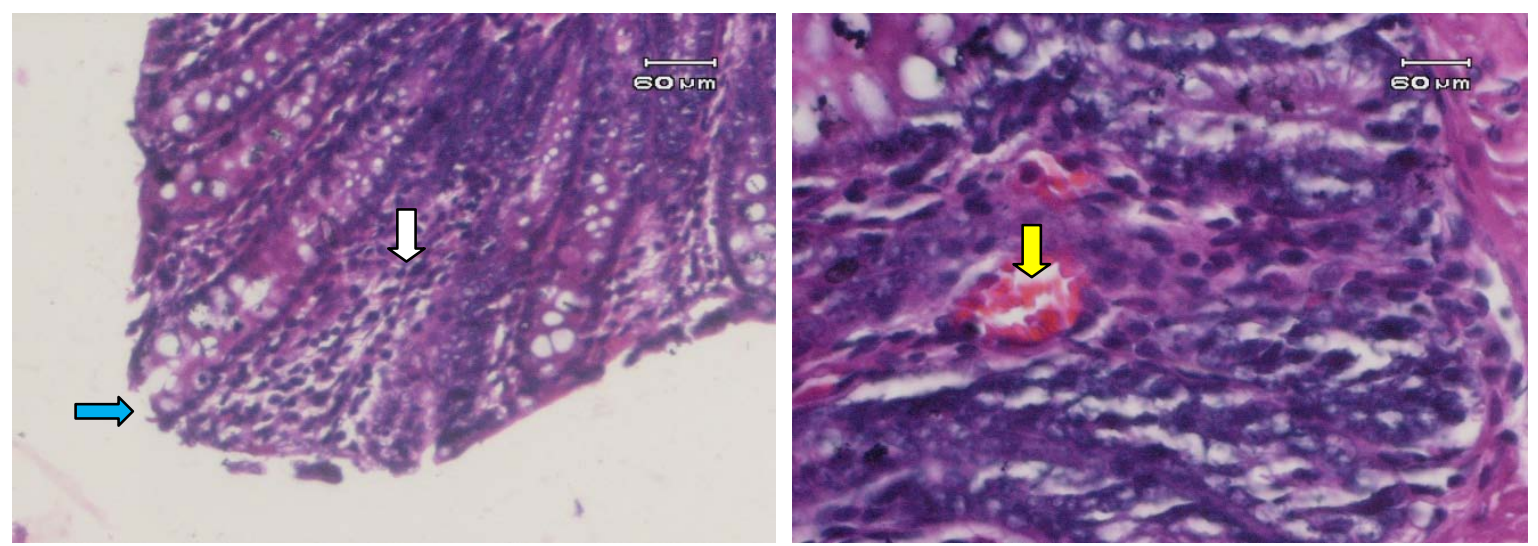

Gambar 2. Gambaran mikroskopik jaringan usus tikus wistar kelompok II. Epitel permukaan yang mengalami erosi (panah biru), limfosit yang banyak (panah putih) menandakan adanya peradangan, dan pelebaran pembuluh darah kapiler (panah kuning). Pembesaran 20x10 dan 40x10. 

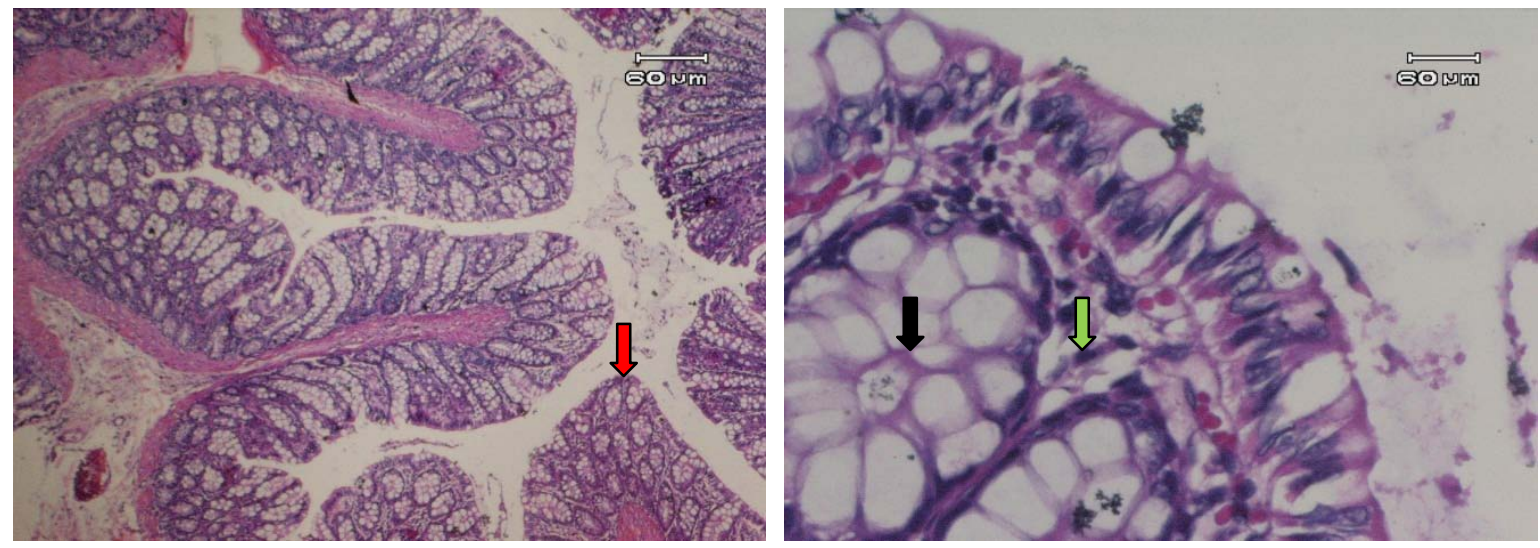

Gambar 4. Gambaran mikroskopik jaringan usus tikus wistar kelompok IV. Epitel permukaan terlihat utuh (panah merah), regenerasi sel goblet (panah hitam), dan jumlah limfosit yang sedikit (panah hijau). Pembesaran 4x10 dan 40x10.

\section{Tikus wistar kelompok IV}

Tikus wistar kelompok IV merupakan kelompok tikus yang diberi E.coli $10^{6} \mathrm{CFU}$ (1ml) selama 7 hari dilanjutkan dengan pemberian Lactobacillus $5 \times 10^{9} \mathrm{CFU}(0,3 \mathrm{mg})$ selama 5 hari. Arsitektur mukosa usus halus normal dengan epitel permukaan yang utuh, adanya regenerasi sel ditandai dengan bertambahnya sel goblet, dan sedikit limfosit (Gambar 4).

\section{BAHASAN}

Pemberian E.coli pada penelitian ini menyebabkan perubahan-perubahan mikroskopik pada jaringan usus. Kelompok tikus yang diberikan E.coli selama 7 hari (kelompok II) memiliki usus halus yang pada beberapa bagian mukosanya terdapat erosi epitel permukaan dan banyak limfosit pada lamina propia dan muskularis mukosa sampai submukosa dan pelebaran pembuluh darah kapiler. E.coli yang bersifat patogen yang menempel pada lapisan mukosa dapat menyebabkan erosi sel-sel epitel permukaan dan peradangan usus halus. Gambaran mikroskopis usus halus yang berbeda ditemukan pada tikus yang mendapat perlakuan E.coli dan Lactobacillus secara bersama-sama (kelompok III). Pada kelompok ini tampak arsitektur mukosa usus halus normal dengan permukaan epitel mukosa yang utuh, jumlah limfosit yang sedikit dan tidak ada pelebaran pembuluh darah kapiler. Probiotik menciptakan keseimbangan flora usus dengan menurunkan jumlah bakteri patogen dan meningkatkan bakteri nonpatogen, mencegah berbagai kelainan, dan menyembuhkan penyakit. Bakteri yang terkandung dalam probiotik beraksi melawan bakteri patogen penyebab infeksi saluran cerna. Probiotik memiliki efek antimikroba yang berperan menghancurkan mikroorganisme yang merugikan. ${ }^{4,6}$

Terdapat banyak laporan tentang penggunaan probiotik dalam penatalaksanaan diare akut. Beberapa studi membuktikan manfaat probiotik pada diare akut terutama dalam hal mempersingkat durasi diare akut. Sejauh ini studi-studi yang telah dilakukan terbatas pada beberapa galur probiotik dimana hasilnya belum tentu mewakili seluruh galur karena adanya sifat strain spesifik. Sampai saat ini Food and Drugs Administration (FDA) belum memberikan persetujuan terkait probiotik sebagai suatu obat di Amerika Serikat. ${ }^{4}$

Strain paling penting dari probiotik adalah Lactobacillus. Bakteri ini menghambat pertumbuhan mikroorganisme patogen dengan cara memproduksi antibiotik alami dan substansi penghambat lain seperti asam laktat dan $\mathrm{H}_{2} \mathrm{O}_{2}$. Lactobacillus dapat memodulasi sistem imun untuk mencegah penyakit peradangan usus. Bakteri ini juga berperan sebagai bakteri kompetitor bagi bakteri patogen 
pada reseptor adhesi sehingga bakteri patogen tidak mampu lagi untuk membentuk koloni dan akhirnya dapat mencegah timbulnya penyakit. $^{7}$

Probiotik menghasilkan substansi yang dikenal sebagai bakteriosin, suatu protein yang dimetabolisme secara aktif dan berperan menghancurkan mikroorganisme yang merugikan. Probiotik mempunyai efek pada ekskresi gen mucin yang akan menstimulasi produksi mukus dari mukosa usus sehingga fungsi barier mukosa usus makin meningkat. ${ }^{4}$ Efek probiotik ini juga tampak pada tikus-tikus yang diberikan E.coli selama 7 hari dilanjutkan dengan pemberian Lactobacillus selama 5 hari (kelompok IV). Gambaran mikroskopik menunjukkan arsitektur mukosa usus halus normal dengan permukaan epitel yang utuh, adanya regenerasi sel yang ditandai dengan bertambahnya sel goblet, dan sedikit limfosit. Pada usus halus, stem sel adalah struktur terkecil dari epitelium. Stem sel berlokalisasi di sekitar sel panet di dalam usus halus. Vilus berdiferensiasi dengan banyak stem sel untuk melakukan regenerasi epitelium. Proses regenerasi epitelium berlangsung selama 3 sampai 5 hari. ${ }^{8}$

Berdasarkan hasil penelitian Arief et al (2008) $)^{5}$, terdapat sepuluh spesies bakteri asam laktat (BAL) yang mempunyai sifat dasar sebagai probiotik dan menghasilkan senyawa antimikroba. Kesepuluh BAL tersebut diuji berdasarkan daya hambat terhadap EPEC dan ketahanan terhadap garam empedu sehingga diperoleh dua jenis BAL, yaitu Lactobacillus acidophilus dan Lactobacillus plantarum. ${ }^{5}$

Lactobacillus yang diberikan setelah tikus diinfeksi dengan E.coli (kelompok IV) terbukti dapat memperbaiki kerusakan yang disebabkan oleh E.coli pada usus halus. Pada kelompok tikus ini usus halus terlihat normal dengan banyak sel goblet.

\section{SIMPULAN}

Dari penelitian ini dapat disimpulkan bahwa pemberian Lactobacillus bersamaan dengan atau setelah pemberian E.coli memberi efek yang baik berupa perbaikan sel epitel permukaan (regenerasi sel epitel dan bertambahnya sel goblet) dan tidak terlihat denudasi epitel permukaan usus halus yang disebabkan oleh E.coli.

\section{UCAPAN TERIMA KASIH}

Ucapan terima kasih disampaikan pada semua pihak yang baik secara langsung maupun tidak langsung telah menumbuhkan ide atau gagasan dalam pemikiran penulis sehingga dapat menyelesaikan artikel ini.

\section{DAFTAR PUSTAKA}

1. Yongsi HBN. Pathogenic microorganisms associated with childhood diarrhea in lowand-middle income countries: Case study of Yaoundé-Cameroon. Int. J. Environ. Res. Public Health. 2008;5:213-29. DOI: 10.3390/ijerph5040213.

2. Farnas H. Angka Kejadian Diare di Kalangan Mahasiswa Universitas Sumatera Utara [Skripsi]. Medan: Fakultas Kedokteran Universitas Sumatera Utara; 2009.

3. Keputusan Menteri Kesehatan Republik Indonesia Nomor 852/MENKES/SK/IX/ 2008 Tentang Strategi Nasional Sanitasi Total Berbasis Masyarakat. Jakarta: DEPKES RI; 2008.

4. Gunawan S. Peran probiotik pada diare akut anak. Pediatric. Ebers Papyrus. 2007;13(3):113-23.

5. Astawan M, Wresdiyati T, I Arief, $E$ Suhesti. Gambaran hematologi tikus Putih yang diinfeksi Escherichia coli enteropatogenik dan diberikan probiotik. Media Peternakan. 2011;April:7-13.

6. Kurniawan I, Simadibrata M. The role of probiotics to improve gut health in the elderly. Med J Indones. 2011;20:226-31.

7. Muchtar AA. Pengaruh pemberian lactobacillus acidophilus terhadap angka kuman usus halus tikus yang diinfeksi shigella dysenteriae. Yogyakarta: Universitas Muhamadiyah; 2010.

8. Abbas $\mathbf{K}$, Aster $\mathbf{F}$, editors. Tissue renewel, repair, and regeneration. In: Robbins and Cotran-Pathologic Basic of Disease (Eigth Edition). Philadelphia: Saunders; 2010. 